\title{
EFFECT ON PERCEIVED STIMULATION DAN PERCEIVED CROWDING ON THE DECISION OF THE UNPLANNED PURCHASE (IMPULSE BUYING)
}

\author{
Enggal Sriwardiningsih \\ Jurusan Manajemen, Fakultas Ekonomi dan Komunikasi, BINUS University \\ Jln. K.H. Syahdan No. 9, Palmerah, Jakarta Barat 11480 \\ enggalnabeel@yahoo.com
}

\begin{abstract}
Purchase decisions aren't made necessarily planned, because impulsive buying is such a result of environmental stimuli shopping. Things affecting unplanned purchasing decisions are perceived by stimulation and crowding. The purpose of this study is to determine whether there are influences between perceived crowding and stimulation of impulse buying simultaneously or partial. The object used is one of the largest retailers in Cilegon. This research design is quantitative analysis of the consumer unit. The collecting data technique includes using questionnaires, interviews, and literature from previous research. Data processed using the SPSS 16.0 program through the validity and reliability, normality test, and regression analysis. The study states that there is significant influence between perceived crowding and perceived stimulation both simultaneous and partial response to impulse buying.
\end{abstract}

Keywords: perceived stimulation, perceived crowding, impulse buying

\begin{abstract}
ABSTRAK
Keputusan pembelian tidak harus direncanakan, karena pembelian yang tidak terencana (impulse buying) merupakan akibat lingkungan rangsangan belanja. Hal-hal yang mempengaruhi keputusan pembelian yang tidak direncanakan antara lain perceived crowding dan perceived stimulation. Tujuan dari studi ini adalah untuk menentukan apakah ada pengaruh antara perceived crowding dan perceived stimulation tidak direncanakan baik secara bersamaan atau sebagian. Objek yang digunakan adalah salah satu pengecer terbesar di Cilegon. Jenis penelitian ini analisis kuantitatif unit konsumen. Pengumpulan data teknik menggunakan kuesioner, wawancara, dan sastra dari penelitian sebelumnya. Data diproses menggunakan program SPSS 16,0 melalui validitas dan kehandalan, normalitas tes, dan analisis regresi. Penelitian menunjukkan bahwa terdapat pengaruh yang bermakna antara perceived crowding dan perceived stimulation secara bersamaan dan sebagian dengan pembelian yang tidak direncanakan.
\end{abstract}

Kata kunci: perceived stimulation, perceived crowding, pembelian tidak terencana 


\section{INTRODUCTION}

Customers can become the company's most valuable asset, so companies need to create while keeping the equity (Mittal, 2004). The company needed effective customer information from the shop space and develops a stimulus to product purchasing behavior in general. Retailers need the information to make shop space as one strategy to compete against competitors (Gronroos, 1990).

The service environment affecting consumer behavior has been widely accepted in literature, marketing literature (Mattila \& Wirtz, 2001). Comfortable environment can cause consumers to spend more time and spend more money than had been budgeted (Rossiter \& Percy, 1997). Mattila \& Wirtz (2008) showed that over-stimulation of the store environment can bring consumers a loss of self control, and therefore contributes to the purchase decision unplanned (impulse buying).

Research by Baker \& Sinkula (1999) stated that there are three dimensions of physical environment factors: ambient factors, design factors, and social factors. Social factors taken in this study is perceived crowding. Mattila (2008) showed that the level of perceived crowding is perceived by consumers in stores; it can affect consumer decisions on all shopping activities. Bellenger in Mattila \& Wirtz (2001), stated that the purchase of unplanned (impulse buying) that occurred in department stores around 27-62 percent of total sales.

Implications of the shopping environment of the purchasing behavior supports the assumption that the services provide a physical environment that influence consumer behavior (Bitner, Booms, \& Tetreault, 1990). Specifically, the documentation about the atmosphere of a neighborhood shopping and retail environment can alter consumer emotions (Rossiter \& Percy, 1997). Emotional changes that alter the mood of consumers buying behavior and the evaluation of the original consumer spending so store can offer an atmosphere or environment that may affect patterns of consumer decision behavior (Keaveney, 1995). Shopping environment and mood can affect a person to make unplanned purchases.

Based on previous studies, researchers conducted a study on the influence of perceived stimulation and perceived crowding on the decision of the unplanned purchase (impulse buying) on a single store to prove whether it also applies to consumer behavior in a particular area. The goal of research is to identify perceived stimulation and perceived crowding influence consumers in deciding the purchase of unplanned (impulse buying) simultaneously.

\section{Understanding Marketing Services}

The definition of services according to Kotler (2002) is any action or activity that can be offered by one party to another, which is essentially intangible and does not result in any ownership. Production may be associated or not associated with a physical product. While Lovelock \& Wirtz (2004) says that services are economic activities offered by one party to another, most commonly employing time defined performances to bring about desired results in recipients themselves or in objects or other assets for the which purchaser have responsibility. While Bitner (1992) gives the definition that service is all economics activities include whose output is not a physical product or contraction is generally consumed at that time it is produced, and provides added value in forms; such as convenience, amusement, comfort, or health.

Service is any act or performance that may be offered one party to another, which is essentially intangible and does not result in ownership of anything. Service characteristics, according to Kotler (2002), there are four characteristics that distinguish services with manufactured goods, as follows: intangible (intangibility), cannot be separated (inseparability), and variable (variability). 


\section{Understanding Retail}

There are several strategies adopted by retailers. According to Levitt (1981), a retail strategy is a statement identifying: (1) the retailers target market; (2) the format of the retailer plans to use satisfy the target market's needs; and (3) the bases upon the which the retailer to build a sustainable competitive advantage. The target market is the market segment(s) toward the retailer plans to focus its resources and retail mix. A retail format is the retailer's mix (the nature of merchandise and services offered, pricing policy, advertising and promotion program, the approach to store design and visual merchandising, and typical location. A sustainable competitive advantage is an advantage over competition that can be maintained over a long time. Retail strategy mix, such as store design, retailers can use to create a sustainable competitive advantage.

\section{Store Environment}

Service environment is an environment where services are processed, delivered, and consumed (Bitner, 1992). The style and appearance of the physical and other surrounding experiential elements encountered by the customer at service delivery sites (Lovelock \& Wirtz, 2004). Customers who come into the store to be affected to take the time to linger in the shopping, shopping for more items and products as well as enjoy the atmosphere created by store management. Environmental forces are larger stores, widespread and affect all behavior in the store environment, that social factors, design factors, the image factor, and ambient factors.

Pasuraman, Zeithmal, \& Berry (1994) classify three dimensions of the service environment: social factors, design, and ambient. Social factors involve the interactions between people in the environmental services Design factor is tangibel such as architecture, style, and layout. Store design is the function of aesthetic or beauty of a store that is reflected through the form of buildings, arrangement of items, and lay out counter. Factors are interesting and fun designs will make consumers feel comfortable Ambient factors is the dimension of the environmental services that affect forming the five human senses, including color, temperature, sound (noise, music), smell, and lighting (Lovelock \& Wirtz, 2004). Communication can occur through the messages conveyed by symbols, giving rise to the perception of consumers in accordance with the wishes of the provider. Ambient factors can affect emotion, perception, and even the attitudes and behavior (Lovelock \& Wirtz, 2004).

Of the several dimensions of ambient factors, the most widely perceived by consumers is the music, color, temperature and lighting. Music can affect the feelings, perceptions, attitudes, and behavior. Color is often done in the area advertising, have proved that the striking colors and soft colors create the psychological effect of different themes and associations. Illumination (lighting) lights can affect one's feelings. Color has shown that low levels of illumination result in a positive affection. While high levels of illumination can is more moving the person. Temperature, psychological research proves that the temperature effect on the affective level. Too high a temperature resulting in longer elapsed time and temperature too low a negative effect on affection (Baker \& Sinkula, 1999).

\section{Perceived Stimulation}

Service environment are stimuli that can affect the feelings, thought (cognition) and someone's behavior (Peter \& Olson, 2005). Bitner (1992) suggested that environmental services can influence the emotions, cognition, and physiological response that could further affect the evaluation and consumer behavior. Mehrabian-Russell model theory, describing how the person's response to stimuli from the environment. Effect of environmental stimuli on the affections or emotions raised by Baker consumers, Levitt (1981) and Rossiter \& Percy (1997). 
Soehadi, Hart \& Tagg (2001) suggests three dimensions of the store environment: ambient, image, social and design, which affect consumer emotions which then affects their behavior. Empirical studies proved the influence of mall environment on the mood of visitors and visitor perceptions of product quality. In addition in his study of the influence of store atmosphere membukitkan stimuli on consumer shopping emotions.

According to Sherman (in Peter \& Olson, 2000) emotional feelings that arise due to external stimuli or stimulus strength. Affection is a response to feelings that arise in the minds of consumers as a result of emotional stimuli (emosion), a certain feeling (specific feelings), mood, and evaluations of the environment. There are actually three dimensions of affect, namely: pleasure (pleasant), arousal (moving), and dominance (control). In its development, affections are divided into two namely: pleasure (fun) and arousal (moving).

Dimensions pleasure begins from unpleasant to pleasant. While the dimensions of arousal begins sleppy (made lazy) to arousing (moving). Affective (emotional state) can occur stelah consumers perceive a stimulus / stimuli from the environment. Perception is the process consumers select, organize, and mengintrepetasi information to form a picture of the surrounding environment (Kotler, 2002). Stimuli are all things that are physical, visual, or verbal communication that may affect consumer responses. Two different consumers have the ability to mengintrepetasikan stimuli are different although the same stimuli.

According to Schiffman \& Kanuk (2000), individuals act on the basis of their perceptions, not on reality. Consumers may form a different perception of the stimuli the same for the three processes of perception, namely: selective exposure, selective distortion, and selective retention.

\section{Perceived crowding}

According to Mattila \& Wirtz (2001), crowding can be defined either from a physical (number of persons in a given space) or from psychological perspective (perceived crowding) (). In the context of perceived crowding the retail level is perceived by consumers, can influence consumer decisions in shopping, as well as the satisfaction in the activity of shopping (Soehadi, Hart \& Tagg, 2001).

The potential customers can provide responses that do not correspond with what is planned by the retailers, such as spending less money than had been planned or leave the store without making a purchase if the perceived high perceived crowding. Perceived negative effects of crowding are also shown in other services such as restaurants and banks.

Whiting (2009), the attitude taken by the consumer faces crowding that occurs at the store: keep shopping, rational thinking, avoiding crowding, leaving the store. Perception of distress are different for the two consumers in the same store. Perceptions of retail crowding seems multidimensional construct consisting of two dimensions: space and social. Perceived by the shoppers crowding cause negative emotions and stress. Given the demonstrated relationship between the emotions triggered by crowding and satisfaction in shopping experience (Soehadi, Hart \& Tagg, 2001).

\section{Impulse Buying}

Impulse buying as an unplanned purchase (Chandra, 2002). The purchase of unplanned purchasing behavior is performed without any problems without any initial or purchase intentions before entering the store. Impulse buying is the purchase of a sudden and done immediately without pre-shopping destination in advance or a product that has been planned in advance. So that consumers do not think about the consequences of the purchases made exactly happened after the purchase (post purchase). That impulse buying is hard to fight because this creates a pleasant experience when shopping. 
Each activity carried out in the consumer purchase decision process would have different motivations underlying. Self-motivation in consumer spending can be divided into two (Sheth \& Parvativar, 1995) which is utilitarian shopping motivation and hedonic shopping motivation. Impulse buying unplanned purchases when consumers experience an urgency to immediately purchase an item that consumer can not reject it. However, impulse buying is not the same as compulsive buying. (Solomon, 1994).

There are four types of classification of impulse buying that can be identified (Chandra, 2002): pure impulse buying reminder buying impulse, impulse buying suggestion, planned impulse buying. However, there are nine ways that are considered the most influence in the impulse buying that is: (1) low price, price consciousness is defined as the degree of consumer sensitivity to price and chances are interested in low prices, while the deal proneness is defined as the tendency of consumers to promotional packages and discount products; (2) marginal need for the convenience items such as packaged goods or health aids and medications. These products are usually not the main goal of consumers in shopping, therefore, rarely included in the products that exist in the list of consumer spending, the purchase occurs largely due to impulse buying; (3) mass distribution, unavailability of a product, can lead to impulse buying for other replacement products; (4) self-services, this system allows consumers to shop faster and more freely than the system serviced; (5) mass advertising, socialization benefits of the product in advertising customers will be able to awaken latent needs that are often unconscious, and therefore then improve the occurrence of impulse buying; (6) prominent store display, setting the composition of the product in a nice shelf, easy reach, and easily visible will certainly attract the attention of consumers; (7) short product life, the shorter the life cycle of a product the higher the likelihood of impulse buying; (8) light weight small size, consumers will more often make impulse buying products with packaging for small because the risk is not too large; (9) ease of storage, products that do not have a problem with the storage would be more apt to occur impulse buying, because although its use can be purchased now at any time. Usually this kind of products consumers buy just in case he will need in the future.

\section{METHOD}

The research approach used is a quantitative approach with a Likert scale where answers were scored from 1 to 5 . The research focuses on evidence drawn from the hypothesis that problem formulation is presented, then using the measured data and will produce a conclusion with a view to generalize. According to, quantitative data is structured so that the range of data obtained from respondents has a variety of patterns and more easily read by the researcher. Because the choice of a particular answer is the answer (data) collected will be for the alternatives. Furthermore, the researchers change the data or the respondents' answers into quantitative units or numbers. The data are the primary data obtained directly from the field either through interviews, questionnaire, and observation.

The process of collecting data in this study will be conducted in the following ways: a preliminary survey by conducting observations and preliminary research, literature studies, field survey. Population is taken from one of the largest stores in Cilegon aged 17 and over, due to the properly access from respondents.

This study used purposive sampling. Selection of purposive sampling technique because researchers have understood that the information needed can be obtained from a particular target group that is able to provide the desired information because they do have such information, and they meet the criteria predetermined by the researcher. While accidental sampling of respondents as the sample is taken by chance, ie, anyone who by chance met the researcher could be used as a sample if the 
person who happens to be found suitable as a data source (Riduwan \& Kuncoro, 2007). Using Slovin Formula (Umar, 2004), reseach Sampling 97 respondents Tests done is test validity, test reliability and test normality.

\section{DISCUSSION}

After passing the test validity, test reliability and test the normality of all data has passed the requirements to valid. Using multiple regression aims to test whether the perceived stimulation (Pleasure and Arousal) as the dependent variable X1 and perceived crowding (Non-crowded, busy activities and lots of visitors) as the independent variable X2 influence consumers in deciding impulse buying (Low price and marginal for the item) simultaneously. The amount of contribution of each independent variable can be seen from table processed regression coefficient below (Table 1).

Table 1 The Amount of contribution of independent variable

\begin{tabular}{|c|c|c|c|c|c|c|}
\hline \multicolumn{7}{|c|}{ Coefficients $^{\mathrm{a}}$} \\
\hline \multirow{2}{*}{\multicolumn{2}{|c|}{ Model }} & \multicolumn{2}{|c|}{$\begin{array}{l}\text { Unstandardized } \\
\text { Coefficients }\end{array}$} & \multirow{2}{*}{$\begin{array}{c}\begin{array}{c}\text { Standardized } \\
\text { Coefficients }\end{array} \\
\text { Beta }\end{array}$} & \multirow[b]{2}{*}{$\mathrm{t}$} & \multirow[b]{2}{*}{ Sig. } \\
\hline & & B & Std. Error & & & \\
\hline 1 & (Constant) & .203 & .159 & & 1.278 & .204 \\
\hline & $\mathrm{x} 1$ & .705 & .068 & .706 & 10.308 & .000 \\
\hline & $x 2$ & .210 & .068 & .212 & 3.090 & .003 \\
\hline
\end{tabular}

a. Dependent Variable: $y$

Model Summary

\begin{tabular}{|l|r|r|r|r|}
\hline Model & \multicolumn{1}{|c|}{$\mathrm{R}$} & \multicolumn{1}{|c|}{ R Square } & Adjusted R Square & $\begin{array}{c}\text { Std. Error of the } \\
\text { Estimate }\end{array}$ \\
\hline 1 & $.852^{\mathrm{a}}$ & .726 & .721 & .42535 \\
\hline
\end{tabular}

a. Predictors: (Constant), x2, x1

\section{Regression function obtained are:}

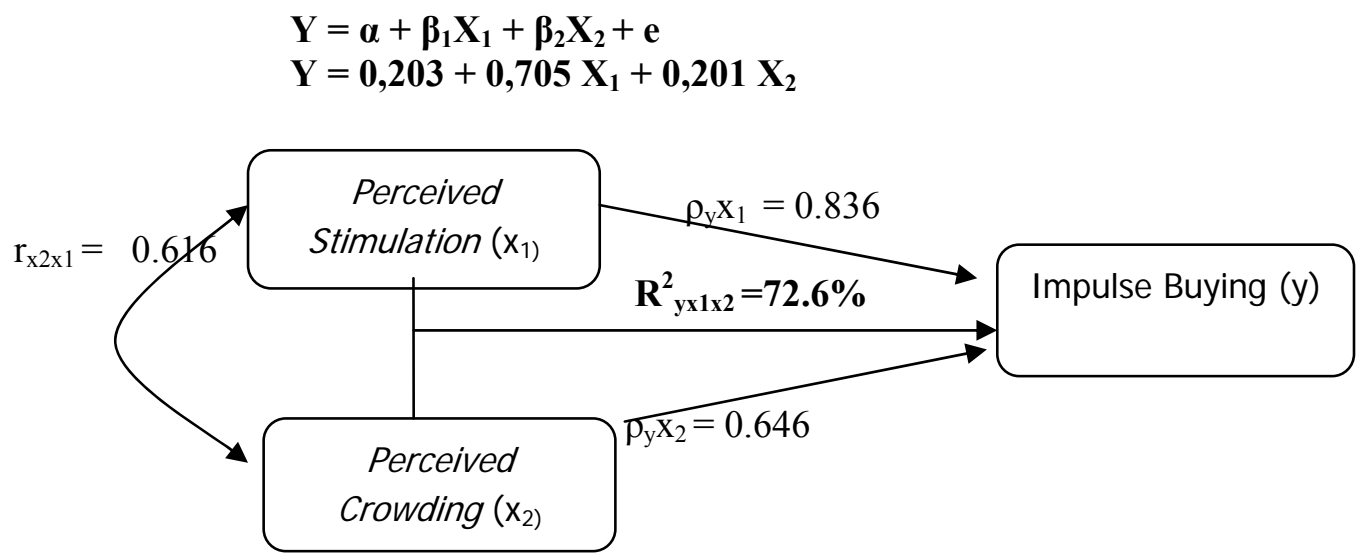

Figure 1 The results of data analysis 
This is supported by the characteristic profile of respondents reflected the results of the questionnaire as follows.

Figure 2 Respondents' profile gender

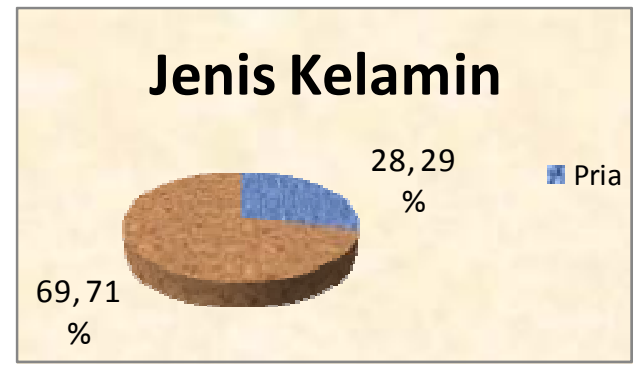

Sources: Primary Data (2011)

Respondents who answered the questionnaires are mostly women at $69.71 \%$. This suggests that women are more affected by stimuli perceived stimulation and perceived crowding. Gender Women are fonder of shopping, then the stimulus of the discount to encourage women to visit and shop somewhere. In addition, women are also more sensitive to the crowd that triggered it.

Figure 3 Respondents' age

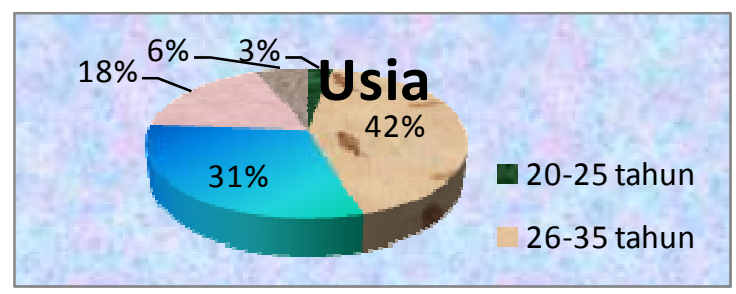

Sources: Primary Data (2011)

26-35 years of age is the age of consumptive society with different needs and desires of diverse compared with other age ranges. This age will tend to be more sensitive to stimuli discounts because many needs that need to be purchased and need not cost a bit which makes them tend to choose products that are discounted. This age range also has a curiosity greater against various forms of crowd, especially those created by a retail store.

Figure 4 Respondents' last education

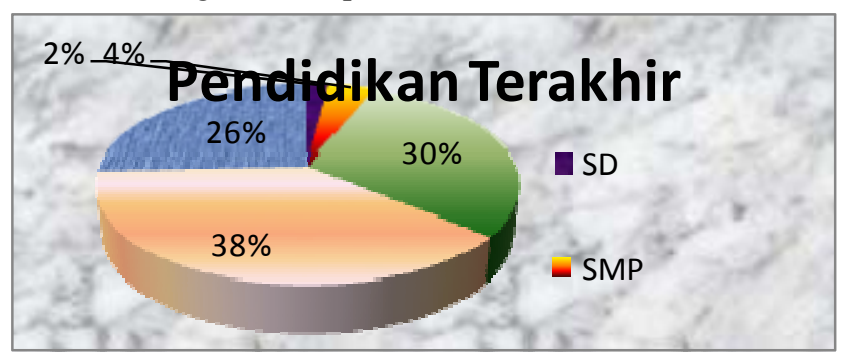

Sources: Primary Data, 2011

Respondents have the most recent education of Diploma / Bachelor of each for 37 people or $38 \%$ of the total number of respondents. With this level of education diploma / degree, people will tend to be affected by the level of discount. This is caused by the calculation of a more critical consumer of the product discounts, product discounts will provide benefits to them of financial terms 
that make it make a purchase at a discount place. Respondents are also more sensitive to the crowd because of the level of education diploma / degree, their curiosity is greater against various things.

Figure 5 Respondents' job

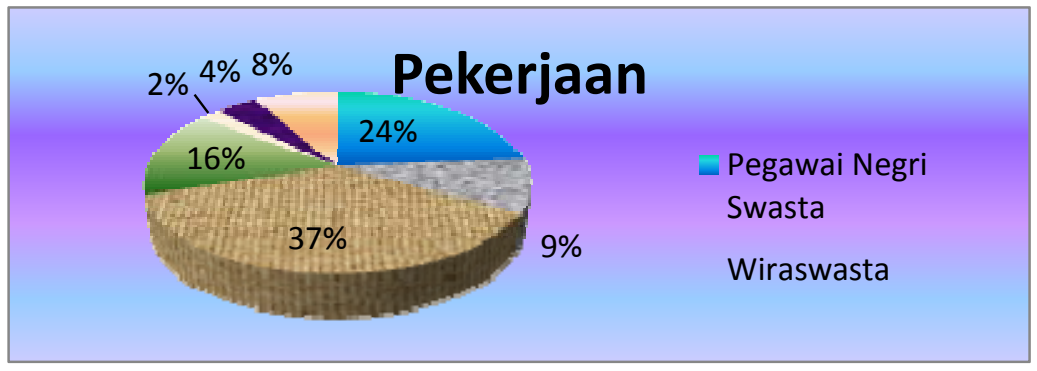

Sources: Primary Data (2011)

From Figure 5, the majority of respondents are private employees with a total of 36 people or $37 \%$ of the total respondents. Private sector employees tend to be more affected by the impulse stimulation such as discounts and bustle of being able to make private sector employees, especially workers to remove and forget all the fatigue from working all day. In addition, they will need more because it interacts with many people in work and requires a lot of equipment to beautify their appearance such as those offered Store.

Figure 6 Respondents' marital status

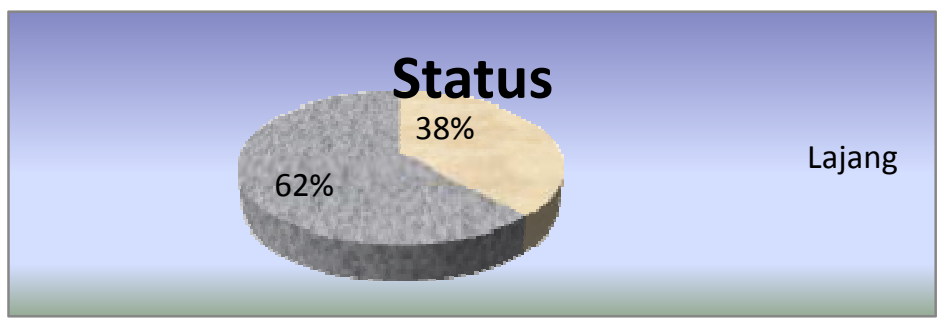

Sources: Primary Data (2011)

Most respondents are married by $62 \%$ or 60 people. Someone who is married will tend to have many and diverse needs. Therefore with the discount, they were able to buy more product than if you buy a product without any discount. In addition, the crowd tends to make them want to know what is going on and offered that meet the needs of their families. This suggests that consumers who are married will likely be affected by stimuli perceived stimulation and perceived crowding.

Figure 7 Respondents' descendants

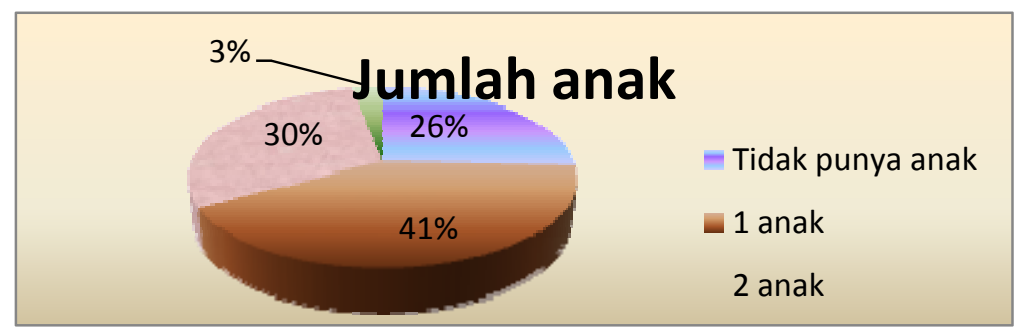

Sources: Primary Data (2011) 
From Figure 7, the majority of respondents have a child. With the children, community needs will increase and more like the product is discounted. Thus, consumers who are married will likely be affected by stimuli perceived stimulation. Furthermore, respondents with a child will have more time to satisfy his curiosity of the crowd when compared with respondents who have many children.

Figure 8 Respondents' monthly expenses

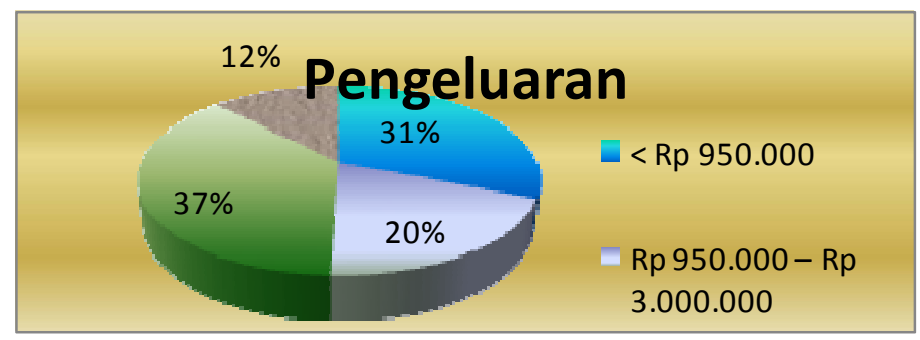

Sources: Primary Data (2011)

From Figure 8, the majority of respondents had expenditures of 3,000,001 IDR to 5,000,000 IDR with a percentage of $37 \%$ of the total respondents. It shows a class of consumers with spending $3,000,001$ IDR to 5 million IDR will likely be affected by stimuli perceived stimulation because of the discounted goods will tend to give the effect of reducing the price by getting more products. The effect of the crowd will also motivate them to larger purchases.

\section{CONCLUSION}

Based on the analysis has been done, there are a variety of findings including perceived stimulation (x1) has a strong relationship with Perceived crowding ( $\mathrm{x} 2)$ for 0.616 ( $\mathrm{rx} 2 \mathrm{x} 1=0.616$ ). Perceived stimulation (x1) has a very strong connection with the Purchase Not Planned (y) for 0.836. Perceived contribution $69.89 \%$ stimulation. This is consistent with research of Tendai \& Crispen (2009). Companies should improve the store environment to increase the perceived stimulation. Procurement research can be carried out to visitors and consumers what they like about visitors layout, lighting, decorations, and various elements in the store environment.

Perceived crowding (x2) has a strong connection with the Purchase Not Planned (y) for 0.646. Donations Perceived crowding (x2) $41.73 \%$. This is consistent with research that has been done by Macheleit, Eroglu, \& Mantel (2000). The atmosphere of a crowded room and the number of visitors as an element of perceived crowding could encourage unplanned purchases. Store can continue to stimulate the perceived crowding of consumers because it will have an impact on unplanned purchases. There is a positive influence between Stimulation and Perceived Perceived crowding against the Purchase Not Planned simultaneously at $72.6 \%$ and the balance of $27.4 \%$ influenced by other variables outside of the study.

\section{Limitations of Research}

This study is limited to one object store for products in the segment of medium income for apparel products. The results of this study might be different if applied in other research objects such as goods that have different sensitivity levels. The existence of factors that have not been read in qualitative research is in the city if there are other great stores to be competitive are to give the same response. Current economic conditions in the study carried out if conditions are not normal, and so forth. Further research should consider the macro-economic factors and strategies in other companies doing the same impact on consumer response. 


\section{REFERENCES}

Baker, W. E., \& Sinkula, J. M. (1999). Learning orientation, market orientation, and innovation: Integrating and extending models of organizational performance. Journal orf Market-Focused Management, Vol.4, No. 4, pp. 295-308.

Bitner, M. J., Booms, B.H., \& Tetreault, M. S. (1990). The service encounter: Diagnosing favorable and unfavorable incidents. Journal of marketing, Vol. 54, No. 1 (January), pp. 71-84.

Bitner, M. J. (1992). Servicescape: The impact of physical surroundings on consumer and employee. Journal of marketing, Vol 56, pp. 57-71.

Chandra, G. (2002), Strategi kepuasan pelanggan vs emosi pelanggan. Paper on Discussion Internal MARKLogic, unpublished, 19 October 2002.

Gronroos, C. (1990). Service management and marketing: Managing the moments of truth in service competition. New York: Lexington Books.

Keaveney, S. M. (1995). Customer switching behavior in service industries: An exploratory study. Journal of marketing, Vol. 59, pp. 71-82.

Kotler, P. (2002). Manajemen pemasaran. Jakarta:Prentice Hall.

Levitt, T. (1981). Marketing intangible products and product intangibles. Harvard business review, May-June, pp.94-102.

Lovelock, C. H., \& Wirtz, J. (2004). Services marketing: People, technology, strategy (5th ed.). Upper Saddle River, New Jersey: Prentice Hall.

Macheleit, K. A, Eroglu, S. A., \& Mantel, S. P. (2000). Perceived retail crowding and shopping satisafaction: What modifies this relationship. Journal of consumer psychology, Vol. 9. No. 1: $29-42$.

Mattila, A. S., \& Wirtz, J. (2001). Congruency of scent and music as a driver of in-store evaluations and behavior. Journal of retailing (Vol. 77). 273-289.

Mattila, A. S. (2008). The role of store environment stimulation and social factors on impulse purchasing. Journal of services marketing, Vol. 22. No. 7: 562-567.

Mittal, B. (2004). Lack of attribute searchability: Some thoughts. Psychology and marketing, Vol.21, No 6, pp.443-462.

Parasuraman, A., Zeithmahl, V. A., \& Berry, L. L. (1994). Alternative scales for measuring service quality: A comparative assessment based on psychometric and diagnostic criteria. Journal of Retailing, Vol. 70, No. 3, pp. 201-230.

Peter, J. P., \& Olson, J. C. (2000). Consumer behavior: Perilaku konsumen dan strategi pemasaran. (D. Sihombing, terj.). Jakarta: Erlangga.

Riduwan, \& Kuncoro, E. A. (2007). Cara menggunakan dan memaknai analisis jalur (path analysis). Bandung: Alfabeta. 
Rossiter, J. R., \& Percy, L. (1997). Advertising communications and promotion management. New York: McGraw-Hill.

Schiffman, L. G., \& Kanuk, L. L. (2000). Consumer behavior (7th ed.). Upper Saddle River, New Jersey: Prentice Hall.

Sheth, J., \& Parvativar, A. (1995). The evolution of relationship marketing. International business review, Vol. 4, pp. 397-418.

Soehadi, A.W., Hart, S., \& Tagg, S. (2001). Measuring market orientation in Indonesia retail context. Journal of strategic marketing, Vol. 9. pp. 285-299.

Solomon, M. (1994). Consumer behavior (2nd ed.). USA: Allyn and Bacon.

Tendai, M., \& Crispen, C. (2009). In-store shopping environment and impulsive buying. African journal of marketing management. Vol. 1. No. 4: 102-108.

Umar, H. (2003). Riset pemasaran dan perilaku konsumen. Jakarta: Gramedia Pustaka Utama.

Whiting, A. (2009). Push, scream, or leave: How do consumers cope with crowded retail stores? Journal of Services Marketing, Vol 23 No. 7: 487-495. 